\title{
Phosphorus Leaching in Sandy Soils. II. Laboratory Studies of the Long-term Effects of the Phosphorus Source
}

\author{
D. M. Weaver, G. S. P. Ritchie and G. C. Anderson
}

\begin{abstract}
Long-term phosphorus (P) losses and gains in sandy soils continuously fertilized with either ordinary superphosphate or coastal superphosphate (a granulated mixture of superphosphate, rock phosphate and elemental sulfur) or previously fertilized with superphosphate were investigated under leaching conditions in columns in the laboratory. The soils were subjected to 10 consecutive cycles designed to simulate the mediterranean weather conditions in the Harvey region of the Coastal Plain of Western Australia. Each cycle consisted of a wet phase during which the equivalent of $850 \mathrm{~mm}$ of rainfall was leached through the soil and a drier phase during which the soil was incubated in the presence of moisture equivalent to summer rainfall $(150 \mathrm{~mm})$. Dissolved inorganic $\mathrm{P}$ in the leachate was used as a measure of $\mathrm{P}$ loss. A sequential fractionation procedure (a resin extraction followed by $0.5 \mathrm{M}$ sodium bicarbonate, $0.1 \mathrm{M}$ sodium hydroxide and $0.1 \mathrm{M}$ sulfuric acid extractions) and total inorganic and organic $P$ were used to measure changes in $P$ levels in the soils.

Phosphorus losses from the previously fertilized soils decreased logarithmically with increasing number of cycles. Total inorganic $P$ and resin-extractable $P$ were able to explain $\geqslant 94 \%$ of the variation in $\mathrm{P}$ losses. Addition of either fertilizer increased the amount of $\mathrm{P}$ leached from the soil and $10-40 \%$ more $P$ was leached by adding superphosphate rather than coastal superphosphate. The percentage of the cumulative $P$ lost by leaching decreased with increasing application rate of both fertilizers when expressed as a percentage of the cumulative water plus citrate-soluble $P$ added. Addition of either fertilizer increased the amount of acid-extractable $P$, but coastal superphosphate had a much greater effect than superphosphate. Leaching losses of $P$ were infuenced by fertilizer solubility in the short term $(<1$ year). In the long term, however, the water plus citrate-insoluble $\mathrm{P}$ in the fertilizers also contributed to $\mathrm{P}$ losses by leaching.
\end{abstract}

\section{Introduction}

Sandy soils that are naturally low in iron, aluminium and phosphorus (P) and are highly permeable have been shown to lose $\mathrm{P}$ from applied superphosphate by leaching and runoff (Neller et al. 1951; Smith 1956; Diggle and Bell 1984; Cogger and Duxbury 1984). Even though as much as $90 \%$ of the applied $P$ may be lost by drainage (Neller 1946; Hingston 1959; Gillman 1973), continued long-term applications (up to 50 years) of superphosphate to sandy soils used for pasture production can lead to a slow but steady build-up of $P$ in excess of plant requirements. This has occurred on the deep grey sands of the Swan Coastal Plain of Western Australia (Yeates et al. 1984) which are naturally deficient in $P$ and have low iron and aluminium contents 
(Bettenay et al. 1960). Much of the excess $P$ finds its way into rivers and estuaries via runoff and leaching (Birch 1982). Short-term losses ( $<1$ year) have been shown to depend on the amount and distribution of rainfall and the type and rate of fertilizer applications (Weaver et al. 1987). Little, however, is known about the factors that affect losses of $P$ from sandy soils in the long term $(>1$ year). If $P$ fertilization of these soils was ceased, it is not known how long they would be able to maintain plant growth and what the associated reduction in P losses would be. Similarly, there is no information about the long-term consequences of regular applications of less soluble fertilizers. Therefore, leaching studies by using columns in the laboratory have been carried out to assess $(a)$ the changes in $\mathbf{P}$ losses from soils previously fertilized with superphosphate, $(b)$ the $\mathrm{P}$ loss from soils with maintenance levels of $\mathrm{P}$, and $(c)$ the long-term $P$ losses and gains from sandy soils continually fertilized with ordinary superphosphate or coastal superphosphate, a less soluble $P$ fertilizer recommended for these soils (Yeates et al. 1984). Dissolved inorganic $\mathbf{P}$ in the leachate was used as a measure of $P$ loss. A sequential fractionation procedure (a resin extraction followed by $0.5 \mathrm{M}$ sodium bicarbonate, $0.1 \mathrm{M}$ sodium hydroxide and $0.1 \mathrm{M}$ sulfuric acid extractions) and total inorganic and organic $P$ were used to measure changes in $P$ levels in the soils.

\section{Materials and Methods}

\section{Soils and Fertilizers}

The soils investigated were siliceous sands of the Bassendean Sand Association and have been described in detail by Bettenay et al. (1960) and McArthur and Bettenay (1960). Samples were collected from the 0-10 cm layer of two Joel soils (Uc 2.33, Northcote classification); one (high-P) contained $26 \mathrm{\mu g} \mathrm{g}^{-1}$ of bicarbonate-extractable $\mathrm{P}$ (Colwell 1963), had been under pasture for more than 20 years and had received annual applications of superphosphate, supplying $P$ at an average rate of $33 \mathrm{~kg} \mathrm{Pha}^{-1} \mathrm{yr}^{-1}$ and the other (low-P) contained $11 \mu \mathrm{g} \mathrm{g}^{-1}$ of bicarbonate-extractable $\mathrm{P}$, had been under pasture for 10 years and had received annual applications of superphosphate, supplying $\mathrm{P}$ at an average rate of $18 \mathrm{~kg} \mathrm{Pha}^{-1} \mathrm{yr}^{-1}$. Both soils were air-dried and sieved $(<2 \mathrm{~mm})$ before use.

The fertilizers used in the experiments were ordinary superphosphate and coastal superphosphate. Coastal superphosphate is a granulated mixture of equal parts of ordinary superphosphate, rock phosphate and elemental sulfur (Yeates et al. 1984). Of the total $\mathrm{P}(10.0 \%)$ in superphosphate, $84 \%$ is water-soluble and $9 \%$ is citrate-soluble (determined on the residue after water extraction). In coastal superphosphate, however, $20 \%$ of the total $\mathrm{P}(9.8 \%)$ is water-soluble and $13 \%$ of the total $\mathrm{P}$ is citrate-soluble.

\section{Phosphorus Losses from Previously Fertilized Soils}

The effect of the level and form of native and previously applied $P$ on long-term leaching losses of $P$ was investigated in the laboratory by subjecting the two soils to 10 consecutive cycles designed to simulate the mediterranean weather pattern of the Swan Coastal Plain of Western Australia. The cycle consisted of a wet phase when the soils were leached with a volume of deionized water equivalent to $850 \mathrm{~mm}$ of rain followed by a drier phase during which the soils were incubated. Both soils were packed into $10 \mathrm{~cm}$ leaching columns and then wet to saturation from below with deionized water by suction. The wet phase of the cycle was imposed first and the leachate was subsampled at various times, filtered $(<0.45 \mu \mathrm{m})$ and analysed for $P$ by the molybdenum blue method of John (1970). The P lost was estimated by the volume of leachate collected at each sampling and the concentration of $P$ in the sample collected. The dry phase consisted of incubation at ambient temperature for 5 days and then at $70^{\circ} \mathrm{C}$ for 14 days. A volume of deionized water equivalent to $150 \mathrm{~mm}$ of rain was also added during the dry phase (as described by Weaver et al. 1987) to simulate summer rain that wets the soil but does not cause drainage. After each complete cycle the soils were mixed and subsampled. Inorganic $\mathrm{P}$ in triplicate subsamples was fractionated according to a modified procedure of Hedley et al. 
$(1982 b)$. The $\mathrm{P}$ was sequentially extracted from the soil by an anionic resin, $0.5 \mathrm{M}$ sodium bicarbonate, $0.1 \mathrm{M}$ sodium hydroxide and finally $0.1 \mathrm{M}$ sulfuric acid. These fractions are referred to as resin-, bicarbonate-, alkali- and acid-extractable. The original method was modified by deleting the residual $P$ step and replacing the $1 \mathrm{M} \mathrm{HCl}$ step with $0.1 \mathrm{M} \mathrm{H}_{2} \mathrm{SO}_{4}$. In addition, total inorganic $P$ and total organic $P$ (Saunders and Williams 1955) were determined on subsamples obtained from the third to the seventh cycles. There was insufficient soil to carry out more than one analysis of total inorganic and total organic $P$.

\section{Phosphorus Losses and Gains in Continuously Fertilized Soils}

The effect of continuous application of superphosphate or coastal superphosphate on long-term losses and gains of $P$ was also investigated. Samples of the low-P soil were packed into $10 \mathrm{~cm}$ leaching columns as described previously. Ground $(<180 \mu \mathrm{m})$ superphosphate or coastal superphosphate was applied to the soil surface at rates of 5,10 and $20 \mathrm{~kg} \mathrm{Pha}^{-1}$ to $10 \mathrm{~cm}$ depth (equivalent to $3.9,7.8$ and $15.6 \mu \mathrm{g} \mathrm{g}^{-1}$ ). The experimental procedure was exactly as described for the previous experiment except that fertilizer was applied at the same initial rate after the soil had been mixed, subsampled and re-packed at the end of each complete cycle. Inorganic $P$ was determined by the modified fractionation method used in the previous experiment.

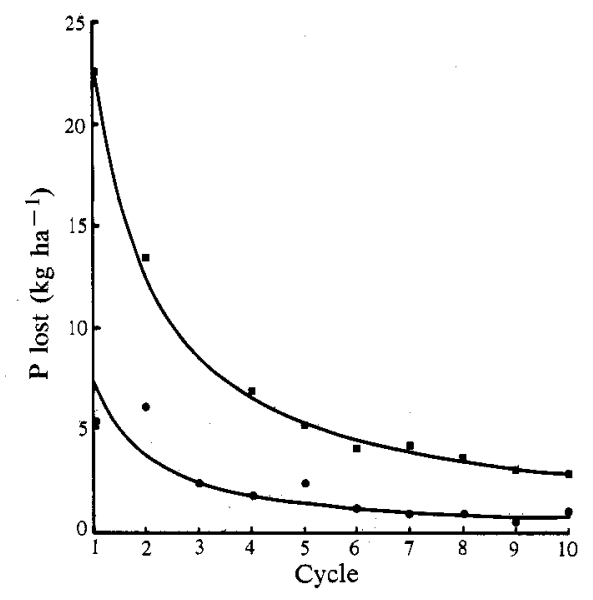

Fig. 1. Phosphorus leached in the wet phase of consecutive cycles from the previously fertilized high-P soil (a) and low-P soil (e).

\section{Results}

\section{Phosphorus Losses from Previously Fertilized Soils}

Phosphorus losses from the previously fertilized soils decreased logarithmically with increasing number of cycles (Fig. 1). The loss of $\mathbf{P}$ during each leaching event from the high-P soil decreased markedly in the first four cycles, followed by a more gradual decrease in loss. For the low-P soil, the loss per cycle decreased more gradually, but was still logarithmic in nature.

In the low-P soil, total organic $\mathbf{P}$ represented $>70 \%$ of the total $\mathrm{P}$ and from the third to the seventh cycles had decreased from 15 to $10 \mu \mathrm{g} \mathrm{g}^{-1}$ (Fig. $2 b$ ). Total organic $\mathrm{P}$ in the high-P soil ( $\sim 50 \%$ of total $\mathrm{P}$ ) decreased from $45 \mu \mathrm{g} \mathrm{g}^{-1}$ after the third cycle to $22 \mu \mathrm{g} \mathrm{g}^{-1}$ at the end of the seventh cycle (Fig. $2 b$ ). In both cases, however, the change between consecutive cycles was erratic. Total inorganic $\mathrm{P}$ consistently decreased between the third and seventh cycles in both soils (Fig. 2.b).

The majority of the $P$ extracted by the sequential fractionation procedure was acid-extractable, whereas the bicarbonate and alkali extracts contained the least 
P ( $<10 \%$, data not shown). After the sixth cycle, therefore, the fractionation procedure was further modified to a resin extraction followed only by an acid extraction. Prior to the first leaching event, the high-P soil contained $17.7 \mu \mathrm{g} \mathrm{g}^{-1}$ resin-extractable $P$ and $31.5 \mu \mathrm{g} \mathrm{g}^{-1}$ acid-extractable $P$ and the low-P soil contained $6.0 \mu \mathrm{g} \mathrm{g}^{-1}$ resin-extractable $P$ and $4.3 \mu \mathrm{g} \mathrm{g}^{-1}$ acid-extractable $P$. Over the 10 cycles, the acid-extractable $\mathrm{P}$ of the high-P soil had decreased (Fig. $2 a$ ). The levels of resinand acid-extractable $P$ were much smaller $\left(<6 \mu \mathrm{g} \mathrm{g}^{-1}\right)$ in the low-P soil, and there was no marked change in the levels after 10 cycles (Fig. $2 a$ ).

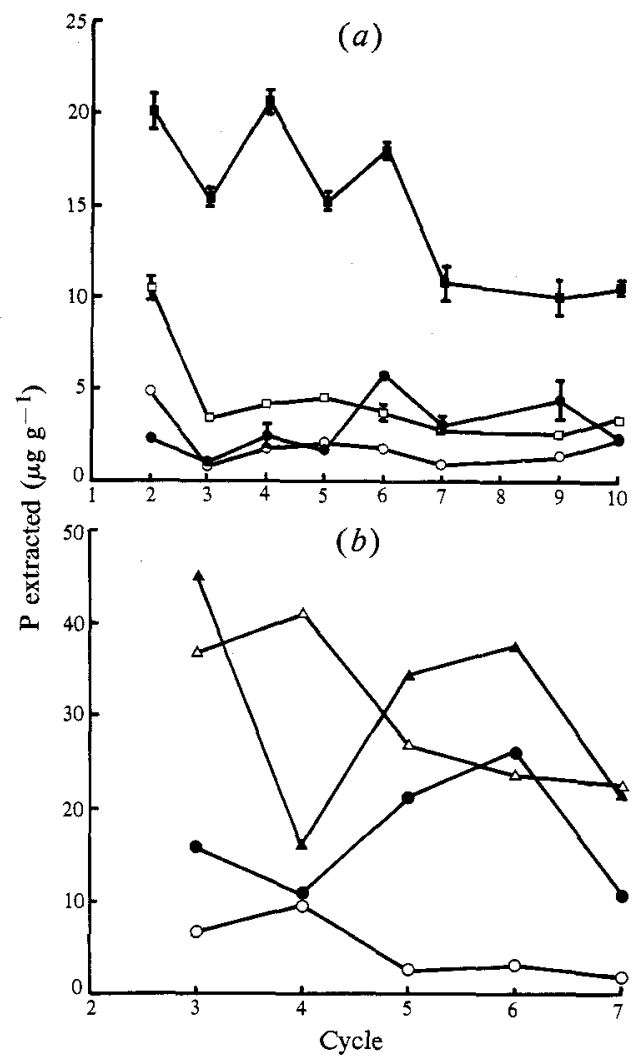

Fig. 2. (a) Resin-extractable phosphorus (open symbols) and acid-extractable phosphorus (closed symbols) measured in the previously fertilized high-P $(\boldsymbol{\omega}, \square)$ and low-P $(\bullet, 0)$ soils after each consecutive cycle. Error bars show standard error of mean (SEM); SEM values less than the width of the points are not visible. (b) Total organic phosphorus (closed symbols) and total inorganic phosphorus (open symbols) measured in the previously fertilized high-P $(\Delta, \Delta)$ and low-P $(\bullet, 0)$ soils after each consecutive cycle.

For both soils, total inorganic $P(x)$ was correlated with the sum of the $P$ extracted by the fractionation procedure $\left(y=4.60+0.58 x ; r^{2}=0.85\right)$ and acid-extractable $P$ $\left(y=1.17+0.47 x ; r^{2}=0.85\right.$ ). The fractionation procedure only extracted $\sim 60 \%$ of the total inorganic $P$.

The different methods of $P$ extraction varied in their ability to explain the variation in the $\mathbf{P}$ lost in the wet phase of the following cycle (Table 1). Total inorganic $\mathbf{P}$ and resin-extractable $\mathbf{P}$ were the most highly correlated with $\mathbf{P}$ losses, being able to explain $\geqslant 94 \%$ of the variation (Fig. 3). 
Table 1. Variation in phosphorus losses $\left(\mathrm{kg} \mathrm{ha}^{-1}\right)$ explained by the amount of $P$ extracted $\left(\mu \mathrm{g} \mathrm{g}^{-1}\right)$ by different methods from soils previously fertilized with superphosphate

\begin{tabular}{lc}
\hline \multicolumn{1}{c}{$\begin{array}{c}\text { Extraction } \\
\text { method }\end{array}$} & $\begin{array}{c}\text { \% variation in P losses } \\
\text { explained by extraction method }\end{array}$ \\
\hline Total inorganic $^{\mathrm{A}}$ & 94 \\
Total organic $^{\mathrm{A}}$ & 51 \\
Resin extractable $^{\mathrm{B}}$ & 96 \\
Acid extractable $^{\mathrm{B}}$ & 67 \\
Complete fractionation procedure $^{\mathrm{B}}$ & 74 \\
\hline
\end{tabular}

A Saunders and Williams (1955).

B Modified method of Hedley et al. (1982b).

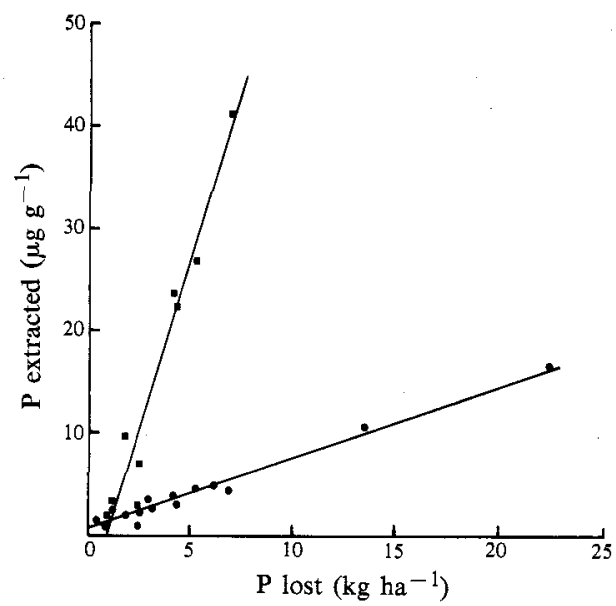

Fig. 3. Relationship between resinextractable phosphorus (๑) and total inorganic phosphorus (D) measured at the end of the dry phase of each cycle and the amount of phosphorus lost during the wet phase of the following cycle.

\section{Phosphorus Losses and Gains in Continuously Fertilized Soils}

The addition of superphosphate or coastal superphosphate increased the amount of $\mathbf{P}$ lost by leaching. The loss in the wet phase of the cycle immediately following the first application was linearly related to the amount of water plus citrate-soluble $\mathbf{P}$ added in the fertilizer regardless of the source (Fig. 4). Between 10\% and $40 \%$ more $\mathbf{P}$ was leached by adding superphosphate rather than coastal superphosphate when compared at equivalent $P$ rates. The cumulative loss of $P$ from coastal superphosphate, expressed as a percentage of the water plus citrate-soluble $\mathrm{P}$ added, was $>100 \%$ for all $\mathrm{P}$ rates after the first cycle (Fig. $5 a$ ). The cumulative loss of $\mathrm{P}$ (expressed as a percentage of the cumulative water plus citrate-soluble $\mathbf{P}$ added) from superphosphate asymptoted at approximately $100 \%$ because $>90 \%$ of the $\mathrm{P}$ was in the water plus citrate-soluble $\mathbf{P}$ form initially (Fig. $5 a$ ). The percentage of the cumulative $\mathbf{P}$ lost by leaching decreased with increasing application rate of both fertilizers when expressed as a percentage of the cumulative $\mathbf{P}$ added (data not shown) or when expressed as a percentage of the cumulative water plus citrate-soluble $\mathbf{P}$ added. The rate of increase in loss of $\mathbf{P}$ from coastal superphosphate in successive cycles was lower than that for superphosphate in the first four cycles when compared with a $\mathbf{P}$ rate of $5 \mathrm{~kg} \mathrm{ha}^{-1}$ 


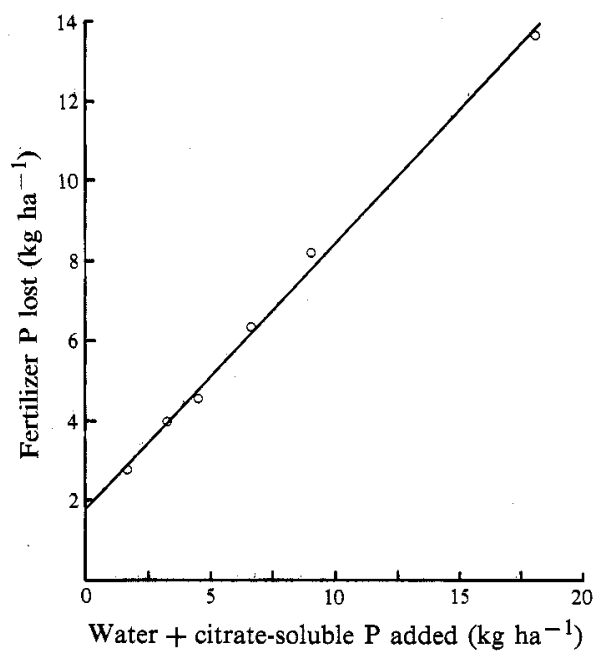

Fig. 4. Relationship between the fertilizer phosphorus lost in the first cycle and the amount of water plus citrate-soluble phosphorus added.
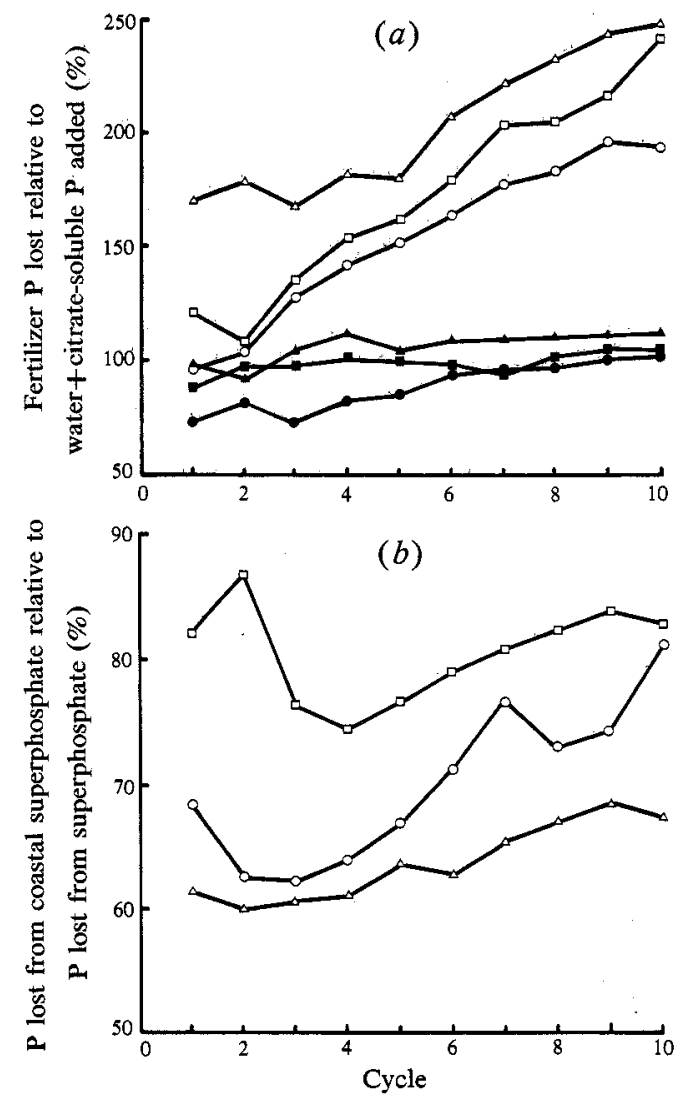

Fig. 5. (a) Cumulative fertilizer phosphorus lost expressed as a percentage of the cumulative water plus citrate-soluble phosphorus added as superphosphate at 5 ( $(\mathbf{)}), 10$ (a) and $20(\bullet) \mathrm{kg} \mathrm{Pha}^{-1}$ and for coastal superphosphate at $5(\Delta), 10$ (口) and 20 (o) $\mathrm{kg} \mathrm{P} \mathrm{ha}{ }^{-1}$ in consecutive cycles. (b) Cumulative phosphorus lost in consecutive cycles from the coastal superphosphate fertilized soil expressed as a percentage of the cumulative phosphorus lost from the superphosphate fertilized soil at rates of $5(\mathrm{c}), 10(0)$ and $20(\Delta)$ $\mathrm{kg} \mathrm{Pha}{ }^{-1}$. 
(3.9 $\mu \mathrm{g} \mathrm{g}^{-1}$ ) (Fig. $5 b$ ). Therefore, the decrease in $\mathbf{P}$ losses from adding coastal superphosphate rather than superphosphate at $5 \mathrm{~kg} \mathrm{P} \mathrm{ha}^{-1}\left(3.9 \mu \mathrm{g} \mathrm{g}^{-1}\right)$ increased up to the fourth cycle. At $P$ rates of 10 and $20 \mathrm{~kg} \mathrm{ha}^{-1}\left(7.8\right.$ and $\left.15.6 \mu \mathrm{g} \mathrm{g}^{-1}\right)$ the rate of increase in loss of $\mathbf{P}$ from coastal superphosphate in successive cycles was approximately the same as for superphosphate up to the fourth cycle. Between the fourth and seventh cycles (at all $P$ rates), the rate of loss of $P$ from coastal superphosphate became greater than that from superphosphate and so the decrease in $\mathbf{P}$ losses from adding coastal superphosphate (at the same $\mathbf{P}$ rate) was not as large (Fig. $5 b$ ). After the seventh cycle, the decrease in the $\mathbf{P}$ lost from adding coastal superphosphate rather than superphosphate (Fig. $5 b$ ) appeared to be approaching a constant value.
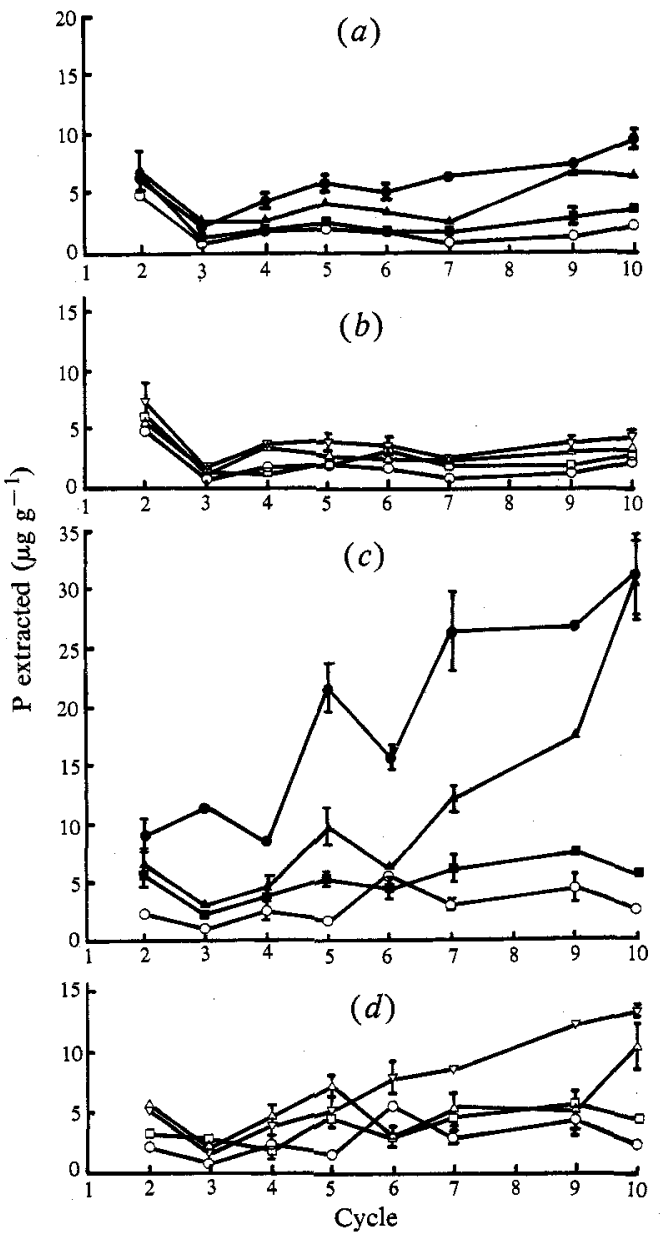

Fig. 6. Resin-extractable phosphorus $(a, b)$ and acid-extractable phosphorus $(c, d)$ measured at the end of each consecutive cycle in the unfertilized soil $(0)$, the soil fertilized with coastal superphosphate at $5(\boldsymbol{\omega}), 10(\Delta)$ and $20(\bullet) \mathrm{kg} \mathrm{P} \mathrm{ha}^{-1}$ per cycle and the soil fertilized with superphosphate at $5(\square), 10(\Delta)$ and $20(\nabla) \mathrm{kg} \mathrm{P}^{-1}$ per cycle. Error bars show standard error of mean (SEM); SEM values less than the width of the points are not visible. 
An increase in the rate of application from 5 to $20 \mathrm{~kg} \mathrm{P} \mathrm{ha}^{-1}\left(3.9-15.6 \mu \mathrm{g} \mathrm{g}^{-1}\right)$ had little effect on resin-extractable $P$ of the soil fertilized with superphosphate (Fig. $6 b$ ), but did increase resin-extractable $P$ in the soil fertilized with coastal superphosphate (Fig. 6a). The application of either fertilizer increased the amount of acid-extractable $P$, but coastal superphosphate (Fig. $6 c$ ) had a much greater effect than superphosphate (Fig. 6d). The increase in acid-extractable $\mathbf{P}$ after the first application of coastal superphosphate was approximately equal to the amount of water plus citrate-insoluble $\mathbf{P}$ added. Acid-extractable $\mathbf{P}$ built up with further applications of either fertilizer; however, the rate of increase was much greater for coastal superphosphate (Fig. 6c) than for superphosphate (Fig. $6 d$ ). After 10 cycles, the sum of $P$ extracted by the fractionation procedure had increased from 5 to $19 \mu \mathrm{g} \mathrm{g}^{-1}$ when superphosphate was applied at a rate of $20 \mathrm{~kg} \mathrm{Pha}^{-1}\left(15.6 \mu \mathrm{g} \mathrm{g}^{-1}\right)$. Over the same time period and at an equivalent application rate, coastal superphosphate increased the sum of $\mathrm{P}$ extracted by the fractionation procedure to $41 \mu \mathrm{g} \mathrm{g}^{-1}$.

\section{Discussion}

The type and amount of applied fertilizer were the major factors influencing long-term $\mathrm{P}$ losses and gains from sandy soils under leaching conditions. In the field, environmental conditions (Weaver et al. 1987), plant uptake and the top dressing (rather than incorporation) of fertilizers would also affect the extent of $\mathbf{P}$ losses. Changes in acid-extractable $P$ reflected the long-term gains and losses of $P$ from sandy soils.

\section{Phosphorus Losses from Previously Fertilized Soils}

The logarithmic decrease in leaching losses with increasing number of cycles probably reflected the low adsorption capacity of the soil and the presence of $P$ that could be rapidly released to the soil solution. Resin-extractable $\mathbf{P}$ was correlated with the $\mathbf{P}$ lost in the next cycle, even though the decrease in resin $\mathbf{P}$ in both soils was small. The relative leaching losses of $\mathbf{P}$ from the high- and low-P soils reflected the difference in the number of years and rate of superphosphate application and their levels of acid-extractable P. Given sufficient time ( $>20$ years), acid-extractable $P$ can build up with continued superphosphate applications to sandy soils, as in the high-P soil.

Under continuous leaching in the laboratory, the $\mathrm{P}$ lost from soils containing sufficient $\mathbf{P}$ for pasture growth $\left(3.9 \mu \mathrm{g} \mathrm{g}^{-1}\right.$ resin-extractable $\left.\mathbf{P}\right)$ was estimated from Fig. 3 to be $4 \mathrm{~kg} \mathrm{Pha}^{-1}\left(\sim 3 \mu \mathrm{g} \mathrm{g}^{-1}\right)$. Previous data, not presented here, have shown that $3.9 \mu \mathrm{g} \mathrm{g}^{-1}$ of resin-extractable $\mathrm{P}$ is equivalent to $8 \mu \mathrm{g} \mathrm{g}^{-1}$ of bicarbonateextractable P (Colwell 1963), which is the minimum level that has been found adequate to maintain pasture production on the Bassendean Sand Association (Yeates et al. 1984). In the field, the loss could be reduced because of plant uptake, or increased because of intermittent leaching (Weaver et al. 1987).

In the high-P soil, the previous applications of superphosphate had led to a build-up of acid-extractable $P$, which then decreased with 10 successive cycles of leaching. Organic $\mathbf{P}$ also decreased but the changes were not systematic and it appeared not to contribute directly to leaching losses as much as acid-extractable $\mathbf{P}$. In the field, however, organic $P$ could be replenished by the death of annual pasture. 
Resin-extractable $\mathbf{P}$ only decreased slightly, presumably because of its continual replenishment from other sources within the soil. Hedley et al. (1982a) suggested that mineralization of organic $P$ occurs to replace $P$ taken up by plants. Sharpley and Smith (1985) considered that if readily available $\mathbf{P}$ exceeds plant requirements it will be depleted by adsorption or by leaching and hence be maintained at a fairly constant level.

Changes in the $\mathbf{P}$ extracted from the low-P soil by the different methods were less marked than in the high-P soil but appeared to follow the same general trend. Resin-extractable $\mathrm{P}$ did not change, presumably because it was replenished from other sources during the dry phase.

\section{Phosphorus Losses and Gains in Continuously Fertilized Soils}

In the long term, water plus citrate-insoluble $P$ was lost from both fertilizers (Fig. 5a), even though short-term losses were related to water plus citrate-soluble $P$ (Fig. 4). Nevertheless, the total amount of $P$ leached by adding coastal superphosphate never equalled that from adding superphosphate, indicating that fertilizer solubility was a major controlling factor.

At all rates of application of superphosphate, only small changes were observed in resin-extractable $\mathbf{P}$ (Fig. $6 b$ ) or acid-extractable $\mathbf{P}$ (Fig. $6 d$ ), because the majority was lost by continuous leaching in the wet phase following application. In addition, the level of water plus citrate-insoluble $\mathbf{P}$ added in each application of superphosphate is small (7\% of added $P$ ) and the number of applications and amount of $\mathbf{P}$ added is small in comparison with the previously fertilized high-P soil, hence an increase in acid-extractable $\mathrm{P}$ may not be observed. In the field, however, other factors such as intermittent leaching and plant uptake would affect extractable P levels (Weaver et al. 1987).

When coastal superphosphate was added to the soil, far less $\mathrm{P}$ was lost by leaching because it contained only $33 \%$ of water plus citrate-soluble P. Ozanne et al. (1961) and Gillman (1973) also found that less P was lost from sandy soils when the source of applied $\mathbf{P}$ was less soluble than superphosphate. In contrast to our study, other research has not indicated that the percentage of $\mathbf{P}$ lost was dependent on the rate of application (Lewis et al. 1981; Ozanne et al. 1961; Logan and McLean 1973; Neller et al. 1951). This may be due to their soils having a higher adsorption capacity.

The extent of long-term losses from continuously fertilized soils cannot be predicted from short-term observations. However, acid-extractable $\mathrm{P}$ can be used to monitor the build-up of $\mathbf{P}$ in sandy soils with a low capacity for $\mathbf{P}$ retention.

Laboratory studies indicated that in the long term, the application of coastal superphosphate, at the rate commonly used for superphosphate on this soil $(18 \mathrm{~kg}$ $P \mathrm{~Pa}^{-1}$ ), could reduce $\mathbf{P}$ losses by $30 \%$. A reduction in the frequency or rate of application may further decrease $\mathbf{P}$ leaching losses.

\section{Acknowledgments}

We wish to thank the Department of Conservation and Environment, Western Australia, for funding this research, and V. Cox and K. Pritchard for technical assistance. 


\section{References}

Bettenay, E., McArthur, W. M., and Hingston, F. J. (1960). The soil associations of part of the Swan Coastal Plain, Western Australia. CSIRO Aust. Soils and Land Use Ser. No. 35.

Birch, P. B. (1982). Phosphorus export from coastal plain drainage to the Peel-Harvey Estuarine system, Western Australia. Aust. J. Mar. Freshwater Res. 33, 23-32.

Cogger, C., and Duxbury, J. M. (1984). Factors affecting phosphorus losses from cultivated organic soils. J. Environ. Qual. 13, 111-14.

Colwell, J. D. (1963). The estimation of phosphorus fertilizer requirements of wheat in southern New South Wales by soil analysis. Aust. J. Exp. Agric. Anim. Husb. 3, 190-7.

Diggle, A. J., and Bell, L. C. (1984). Movement of applied phosphorus following the mining and revegetation of mineral sands on Australia's east coast. Aust. J. Soil. Res. 22, 135-48.

Gillman, G. P. (1973). Studies on some deep sandy soils in Cape York Peninsula, North Queensland. 3. Losses of applied phosphorus and sulphur. Aust. J. Exp. Agric. Anim. Husb. $13,418-22$.

Hedley, M. J., Stewart, J. W. B., and Chauhan, B. S. $(1982 a)$. Changes in inorganic and organic soil phosphorus fractions induced by cultivation practices and by laboratory incubations. Soil Sci. Soc. Am. J. 46, 970-6.

Hedley, M. J., White, R. E., and Nye, P. H. $(1982 b)$. Plant-induced changes in the rhizosphere of rape (Brassica napus var. Emerald) seedlings. III. Changes in $L$ value, soil phosphate fractions and phosphatase activity. New Phytol. 91, 45-56.

Hingston, F. J. (1959). The loss of applied phosphorus and sulphur from soils under pasture in Western Australia. J. Aust. Inst. Agric. Sci. 25, 209-13.

John, M. K. (1970). Colorimetric determination of phosphorus in soil and plant materials with ascorbic acid. Soil Sci. 109, 214-20.

Lewis, D. C., Clarke, A. L., and Hall, W. B. (1981). Factors affecting the retention of phosphorus applied as superphosphate to the sandy soils in south-eastern South Australia. Aust. J. Soil Res. 19, 167-74.

Logan, T. J., and McLean, E. O. (1973). Effects of phosphorus application rate, soil properties, and leaching mode on ${ }^{32} \mathrm{P}$ movement in soil columns. Soil Sci. Soc. Am. Proc. 37, 371-4.

McArthur, W. M., and Bettenay, E. (1960). The development and distribution of the soils of the Swan Coastal Plain, Western Australia. CSIRO Aust. Soil Publ. No. 16.

Neller, J. R. (1946). Mobility of phosphates in sandy soils. Soil Sci. Soc. Am. Proc. 11, 227-30.

Neller, J. R., Jones, D. W., Gammon, N., and Forbes, R. B. (1951). Leaching of fertilizer phosphorus in acid sandy soils as affected by lime. Circ. Fla. Agric. Exp. Sta. No. S-32.

Ozanne, P. G., Kirton, D. J., and Shaw, T. C. (1961). The loss of phosphorus from sandy soils. Aust. J. Agric. Res. 12, 409-23.

Saunders, W. M. H., and Williams, E. G. (1955). Observations on the determination of total organic phosphorus in soils. J. Soil Sci. 6, 248-67.

Sharpley, A. N., and Smith, S. J. (1985). Fractionation of inorganic and organic phosphorus in virgin and cultivated soils. Soil Sci. Soc. Am. J. 49, 127-30.

Smith, P. F. (1956). Effect of phosphate fertilization on root growth, soil $\mathrm{pH}$, and chemical constituents at different depths in an acid sandy Florida citrus soil. Proc. Fla. State Hortic. Soc. 69, 25-9.

Weaver, D. M., Ritchie, G. S. P., Anderson, G. C., and Deeley, D. M. (1987). Phosphorus leaching in sandy soils. I. Short-term effects of fertilizer applications and environmental conditions. Aust. J. Soil Res. 26, 177.

Yeates, J. S., Deeley, D. M., Clarke, M. F., and Allen, D. (1984). Modifying fertilizer practices. J. Agric. West. Aust. 25, 87-91. 